\title{
Lightning activity, rainfall and flash flooding - occasional or interrelated events? A case study in the island of Crete
}

\author{
A. G. Koutroulis ${ }^{1}$, M. G. Grillakis ${ }^{1}$, I. K. Tsanis ${ }^{1,2}$, V. Kotroni ${ }^{3}$, and K. Lagouvardos ${ }^{3}$ \\ ${ }^{1}$ Water Resources Management and Coastal Engineering Laboratory, Environmental Engineering Dept., Technical University \\ of Crete, Greece \\ ${ }^{2}$ Department of Civil Engineering, McMaster University, Hamilton, Canada (on research leave) \\ ${ }^{3}$ Institute for Environmental Research and Sustainable Development, National Observatory of Athens, Greece
}

Correspondence to: I. K. Tsanis (tsanis@mcmaster.ca)

Received: 15 April 2011 - Revised: 2 February 2012 - Accepted: 26 March 2012 - Published: 10 April 2012

\begin{abstract}
The majority of cyclones passing over Crete in late autumn to early winter originate from southwest, west and northwest and are of varying size and intensity. A number of these cyclones cause flash floods. The present study reports the possible relationships between lighting activity and high precipitation related to flash flood events. In this study an attempt was made to correlate the lightning number and location, recorded by the ZEUS lightning detection system, with the rainfall characteristics for sixteen rain events (4 flood and 12 non-flood events) on the island of Crete, during the period 2008-2009. Spatiotemporal analysis of rain and rain rate with flash count was performed with respect to distance (radius) of flashes from raingauge location at various temporal scales, in order to examine the correlation of accumulated rainfall and lightning activity. The maximum attained statistical significant correlation was obtained within a circular area of an average radius of $15 \mathrm{~km}$ around the raingauge, and an average time lag of flash count prior precipitation accumulation of $15 \mathrm{~min}$. The maximum correlation between the lightning and rainfall data is obtained for shorter time lags for the flood events $(15 \mathrm{~min})$ than the non-flood events $(25 \mathrm{~min})$, that could reflect the faster propagation of flood triggering storms due to high convective activity. Results show increased lightning activity occurring during flood triggering storms, by an average of four times higher. Furthermore, there is evidence that the number of flashes that occur during a precipitation event is related to precipitation depth when the latter is adequate to produce a flood event. Differences between flood and non-flood producing storms need to be further assessed by analyzing more independent
\end{abstract}

parameters, including the synoptic conditions and dominant flash flood hydrological generating processes.

\section{Introduction}

Flash floods are one of the most significant natural hazards in Europe and a cause of significant loss of life and economic damage (Gaume et al., 2009). Following droughts, floods are the most dangerous meteorological hazards affecting the Mediterranean countries, as the casualties and damages exceed 4500 deaths and 29 million Euro, respectively, according to a total of 185 recorded flood events between 1990 and 2006 (Llasat et al., 2010). Flash floods often affect ungauged watersheds thus remaining a poorly documented phenomenon (Gaume et al., 2009). Intense storm events are the dominant flash flood triggering factor. These types of floods can seldom be predicted and therefore any new evidence regarding the occurrence of such events can be useful for their mitigation (Koutroulis et al., 2010). Moreover, multilateral approaches reduce uncertainty in the event interpretations (Koutroulis and Tsanis, 2010; Grillakis et al., 2010).

The examination of lightning activity during flash flood events provides improved understanding of the complex hydro-meteorological conditions. Precipitation and lightning observation correlation research is in many cases motivated by the hypothesis that precipitation estimates derived from lightning observations can be used as a short-term prediction system of intense precipitation. This is based on the fact that lightning activity precedes the precipitation evolution, which has been documented in previous studies, like Soula 
et al. (1998). Many studies have been conducted in order to correlate the precipitation characteristics and the lightning activity flashes (Soula and Chauzy, 2001; Tapia et al., 1998; Zhou et al., 2002; Kempf and Krider, 2003; Katsanos et al., 2007; Pineda et al., 2010). Tapia et al. (1998), analyzed lightning observations from 22 thunderstorms in Florida, concluding that it is possible to derive estimates of precipitation in space and time for heavy rainfall events. Their analysis was based on a simple model to estimate convective rainfall from lightning observations. Soula and Chauzy (2001) studied the correlation between lightning and rain activity on four days of thunderstorm activity in France. They found the overall spatial correlation between rain and lightning occurrence to be very consistent for all lightning types. Similar results were obtained by Price and Federmesser (2006) investigating winter storms over central and eastern Mediterranean. Soula et al. (1998) studied the 7 August 1996 flash flood of the Rio Gallego, in Aragon that wiped out the Biescas' campground leaving more than 80 human casualties, and concluded that quantitative information of lightning activity could provide additional information in terms of flashflood nowcasting and short-term forecasting in mountainous areas. Barnolas et al. (2008) used raingauge, radar, GIS and lightning data for the characterization of the 12-14 September 2006 flash flood event of Catalonia within a common classification framework. They concluded that the high lightning activity of the particular event has made it suitable to study the relation between strikes and precipitation, finding that the relation is improved with increased lightning activity. Michaelides et al. (2009) examined the relationship between lightning and rainfall for three depressions which affected the area of Cyprus, based on a rectangular grid-box methodology. This methodology has yielded poor coefficient of determination and negative slopes of the fitted regression lines. For this reason, the authors propose further examination between rainfall variables and lightning data within a circle of varying radius around the station. Furthermore, Michaelides et al. (2010) extended the rainfall-lightning relationship identification for nineteen rainy events in Cyprus, adopting a spatio-temporal statistical methodology resulting to improved correlations. In the frame of the EU funded project FLASH, Harats et al. (2010) proposed lightning and rain dynamic indices for use in short term forecasting of flash floods in the Mediterranean Region, concluding that intense lightning activity might serve as a good predictor for flashfloods. The preliminary qualitative results support further study in order to define quantitative thresholds for the developed indices, potentially serving as a future forecasting tool when applied to the output of regional forecasting model. The general conclusion of previous studies is that lightning information can be successfully used for estimating precipitation characteristics. However, the differences among studies' results indicate the strong relationship of the correlation to thunderstorm type, location, local climatology and convective regime.
The present study aims to examine the correlation between precipitation and lightning activity in the frame of flash-flood nowcasting potential, through a spatio-temporal analysis of sixteen flood and non-flood events that occurred on the island of Crete during the 2008-2009 period.

\section{Study area and datasets}

The island of Crete occupies the southern part of the country of Greece (Fig. 1). With an area of $8265 \mathrm{~km}^{2}$, Crete covers almost $6.3 \%$ of the area of Greece. The mean elevation is $482 \mathrm{~m}$ ranging from sea level to $2450 \mathrm{~m}$ and the average slope $228 \mathrm{~m} \mathrm{~km}^{-1}$ with the topography fracturing into small catchments with ephemeral streams and karst geology. Crete has a typical Mediterranean island environment, with about $40 \%$ of the annual precipitation occurring in the winter months while there is negligible rainfall during summer (Naoum and Tsanis, 2004; Koutroulis and Tsanis, 2010). An extensive analysis of the occurrence and seasonality of floods and their hydrometeorologic characteristics in the island of Crete is reported by Koutroulis et al. (2010).

High temporal resolution rainfall and lightning data were obtained for sixteen intense rainfall events of the 2008-2009 period, listed in Table 1. Evidence of flood occurrence for four of the sixteen events was retrieved in collaboration with the local Civil Protection Service Office of Crete Region that is responsible for recording the impact cost, the location, the date and other information of the flood events over Crete. The rainfall data were provided from a network of twelve high temporal resolution $(10 \mathrm{~min}$.) meteorological stations of the National Observatory of Athens (NOA), (Fig. 1). Furthermore, lightning data was recorded from the ZEUS system and was provided by NOA (Kotroni and Lagouvardos, 2008; Lagouvardos et al., 2009). The ZEUS lightning system is a modern, low-cost experimental long-range lightning detection system based on a network of six "sferics" receivers deployed in Europe, providing a very good coverage of the Eastern Mediterranean. More precisely, ZEUS network detection efficiency and location error has been assessed in comparison with the LINET network over CentralWestern Europe where this latter network presents its highest data quality. The location error of ZEUS was calculated to be $\sim 6.8 \mathrm{~km}$, while the detection efficiency was $\sim 25 \%$, compared to LINET with a characteristic under-detection during night-time (Lagouvardos et al., 2009). No assessment of ZEUS network has been performed over the study area due to the lack of a high density lightning detection network in the area. ZEUS is capable of detecting not only cloud-to-ground but also to a small degree the intra-cloud strokes. The system does not permit to distinguish the detected flashes and thus the total detected number has been used for this study. 


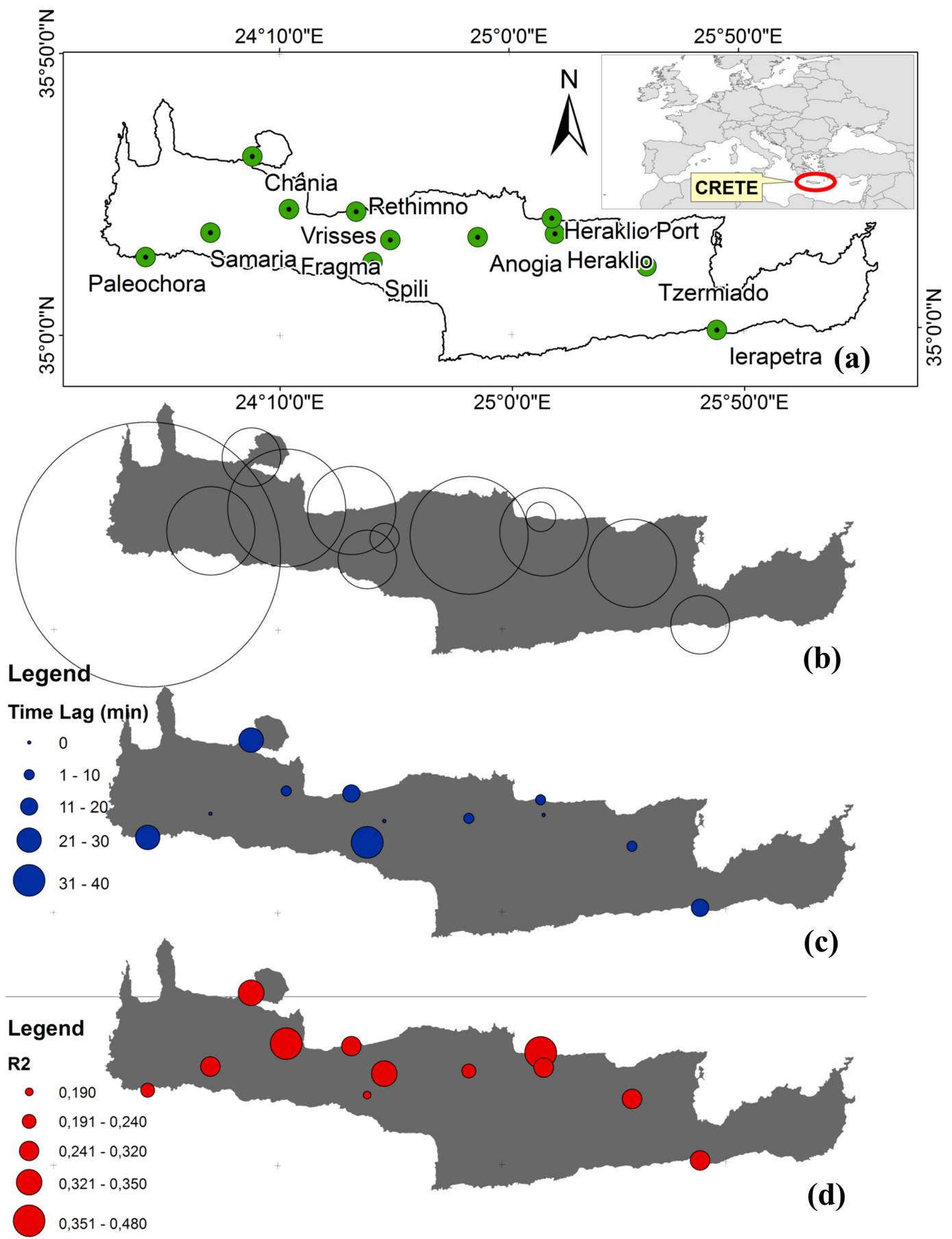

Fig. 1. (a) Location of Crete Island and meteorological stations of National Observatory of Athens (NOA), (b) optimum radius, (c) optimum time-lag and (d) attained $r^{2}$, according to Table 2 results.

\section{Methodology}

Lagged relationships between two variables are common in natural physical systems. Lagged correlation refers to the correlation between two time series shifted in time relative to one another. Lagged correlation is important in studying the relationship between time series, because one series may have a delayed response to the other series. A correlation between the two series properly aligned in time may be inadequate to characterize the relationship in such situations. The analysis of the correlation between precipitation and flash count was based on a multi-spatiotemporal approach. For a specific precipitation event on a specific meteorological 
Table 1. List of intense precipitation events selected for analysis and corresponding event characteristics (duration, value and location of maximum recorded accumulated precipitation, value and location of maximum 10 min precipitation, value and location of maximum 10 min rain rate and location). Flood events marked in bold.

\begin{tabular}{llllllll}
\hline Event & Start & End & $\begin{array}{l}\text { Duration } \\
\text { (h) }\end{array}$ & $\begin{array}{l}\text { Max event scale } \\
\text { accumulated } \\
\text { precipitation }(\mathrm{mm})\end{array}$ & $\begin{array}{l}\text { Location } \\
\text { (station) }\end{array}$ & $\begin{array}{l}\text { Max precipitation } \\
10 \text { min (mm) } \\
\text { time step }\end{array}$ & $\begin{array}{l}\text { Location } \\
\text { (station) }\end{array}$ \\
\hline 1 & $24 / 1 / 200807: 00$ & $25 / 1 / 200802: 00$ & 19 & 45.6 & Vrisses & 8.4 & Chania \\
2 & $8 / 2 / 200800: 00$ & $8 / 2 / 200821: 00$ & 21 & 44.8 & Paleochora & 4.6 & Paleochora \\
3 & $20 / 9 / 200811: 00$ & $21 / 9 / 200802: 00$ & 15 & 35.4 & Samaria & 9.6 & Paleochora \\
4 & $22 / 9 / 200802: 00$ & $22 / 9 / 200819: 00$ & 17 & 17.8 & Spili & 6.0 & Spili \\
$\mathbf{5}$ & $\mathbf{2 2 / 1 1 / 2 0 0 8 ~ 0 0 : 0 0}$ & $\mathbf{2 2 / 1 1 / 2 0 0 8 ~ 1 5 : 0 0}$ & $\mathbf{1 5}$ & $\mathbf{7 3 . 8}$ & Ierapetra & $\mathbf{1 2 . 4}$ & Fragma \\
$\mathbf{6}$ & $\mathbf{2 1 / 1 2 / 2 0 0 8 ~ 1 6 : 0 0}$ & $\mathbf{2 3 / 1 2 / 2 0 0 8 ~ 0 8 : 0 0}$ & $\mathbf{4 0}$ & $\mathbf{1 4 7 . 4}$ & Tzermiado & $\mathbf{5 . 2}$ & Spili \\
7 & $27 / 12 / 200821: 00$ & $28 / 12 / 200813: 00$ & 16 & 22.6 & Tzermiado & 3.4 & Rethimno \\
8 & $25 / 1 / 200906: 00$ & $26 / 1 / 200900: 00$ & 18 & 64.0 & Samaria & 6.4 & Samaria \\
9 & $12 / 2 / 200913: 00$ & $13 / 2 / 200923: 50$ & 53 & 104.8 & Samaria & 3.8 & Samaria \\
$\mathbf{1 0}$ & $\mathbf{4 / 4 / 2 0 0 9 1 5 : 0 0}$ & $\mathbf{5 / 4 / 2 0 0 9} \mathbf{1 5 : 0 0}$ & $\mathbf{2 4}$ & $\mathbf{3 6 . 6}$ & Paleochora & $\mathbf{3 . 4}$ & Heraclio Port \\
11 & $11 / 9 / 200902: 00$ & $11 / 9 / 200914: 00$ & 12 & 49.0 & Tzermiado & 7.0 & Ierapetra \\
12 & $24 / 10 / 200906: 00$ & $25 / 10 / 200900: 00$ & 18 & 100.0 & Vrisses & 14.8 & Vrisses \\
$\mathbf{1 3}$ & $\mathbf{2 5 / 1 0 / 2 0 0 9 ~ 0 2 : 0 0}$ & $\mathbf{2 6 / 1 0 / 2 0 0 9 ~ 0 0 : 0 0}$ & $\mathbf{2 2}$ & $\mathbf{1 4 7 . 6}$ & Tzermiado & $\mathbf{1 3 . 2}$ & Tzermiado \\
14 & $8 / 11 / 200900: 00$ & $8 / 11 / 200909: 00$ & 9 & 50.8 & Heraclio & 15.2 & Heraclio \\
15 & $2 / 12 / 200900: 00$ & $3 / 12 / 200900: 00$ & 24 & 78.6 & Samaria & 11.0 & Spili \\
16 & $10 / 12 / 200913: 00$ & $11 / 12 / 200922: 00$ & 33 & 99.4 & Samaria & 5.6 & Rethimno \\
\hline
\end{tabular}

\begin{tabular}{|c|c|}
\hline 일 & $\begin{array}{c}\text { Hourly Cumulative } \\
\text { Flash count }\end{array}$ \\
\hline$\underline{E} \underline{E}$ & $\begin{array}{l}\text { Hourly Cumulative } \\
\text { Precipitation (mm) }\end{array}$ \\
\hline
\end{tabular}
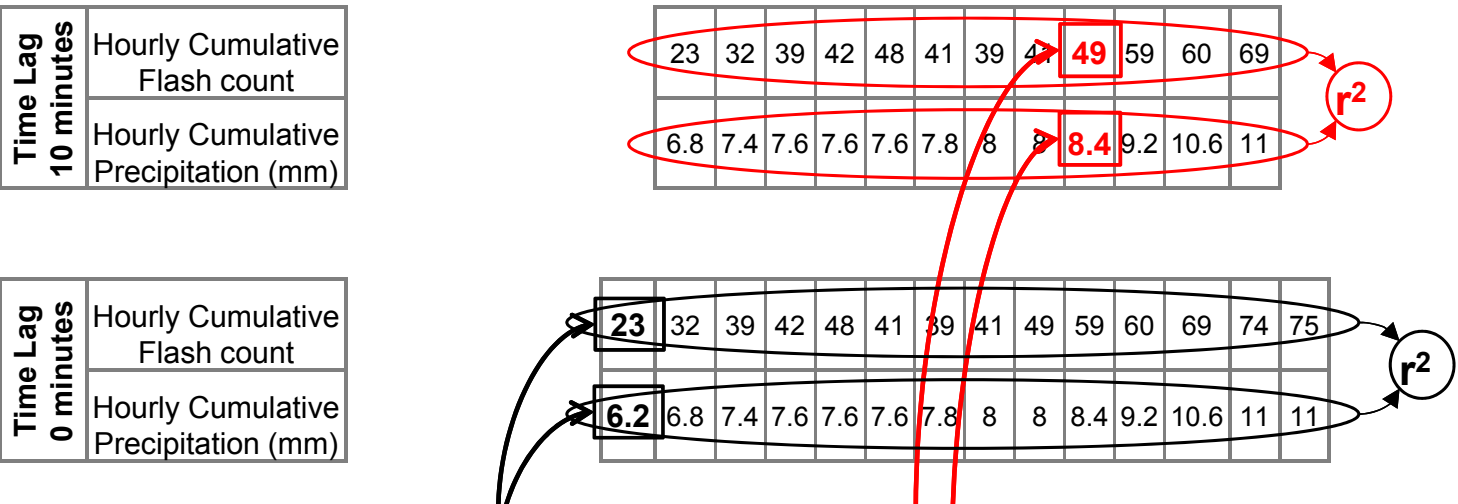

\begin{tabular}{|c|c|c|c|c|c|c|c|c|c|c|c|c|c|c|c|c|c|c|c|}
\hline Flash count & 0 & 4 & 3 & 3 & 7 & 6 & 9 & 11 & 6 & 9 & 0 & 4 & 11 & 19 & 16 & 10 & 9 & 9 & 12 \\
\hline Precipitation (mm) & 0.6 & 0.6 & 1 & 1.2 & 1.6 & 1.2 & 1.2 & 1.2 & 1.2 & 1.2 & 1.6 & 1.4 & 1.4 & 1.2 & 1.6 & 2 & 3 & 1.8 & 1.4 \\
\hline$\underset{\models}{\stackrel{\varpi}{\models}}$ & 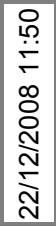 & 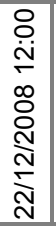 & 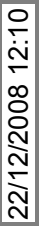 & 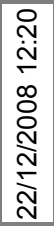 & 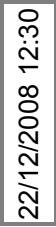 & 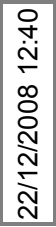 & 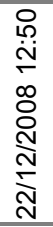 & 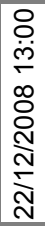 &  & 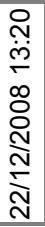 & 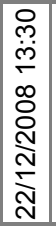 & 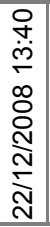 & 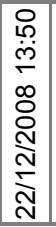 & 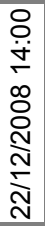 & 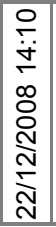 & 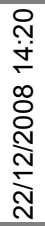 & 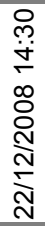 & 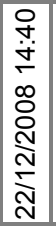 & $\begin{array}{l}\infty \\
\stackrel{్}{0} \\
\end{array}$ \\
\hline
\end{tabular}

Fig. 2. Graphical representation of the methodology for a specific meteorological station, event and effective radius.

station, the number of flashes within a circular area of radius $R$ (with the station at its center) and the total precipitation height for an hourly timeframe was considered. The hourly timeframe was "moving" in a ten minute step synchronously over the precipitation and flash count time series, producing two vectors of data from which coefficient of determination was estimated. The hourly timeframe used for the flash count was also shifted 10, 20, 30, 40, 50 and 60 (time lag - TL) minutes prior the precipitation timeframe, in order to examine the potential of higher correlation between precipitation over a station and past timeframe flash count. The radius $\mathrm{R}$ varied between $5 \mathrm{~km}$ and $50 \mathrm{~km}$ in a $5 \mathrm{~km}$ step. Figure 2 shows a graphical representation of the methodology for a specific meteorological station, event and effective radius. The procedure was applied for 16 events over 12 meteorological stations. The correlation between the 


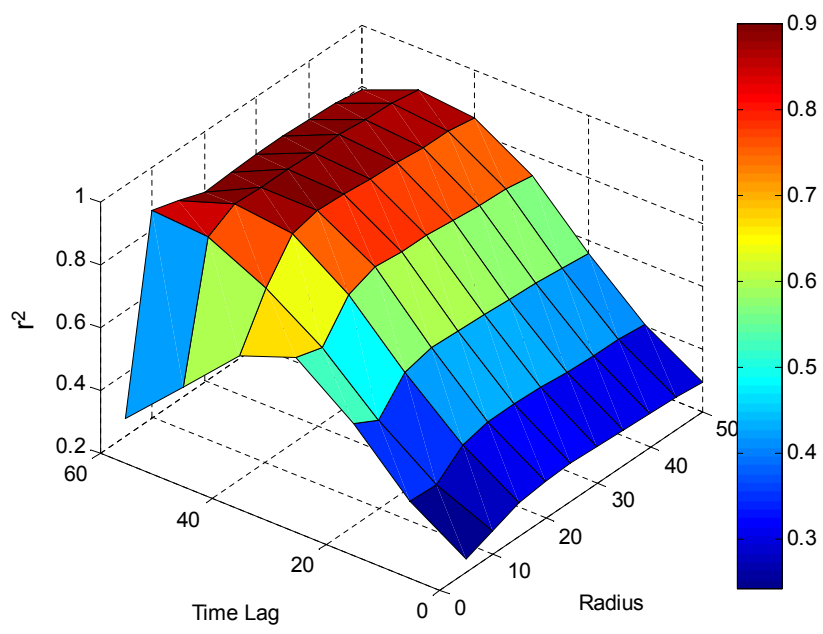

Fig. 3. Example of coefficient of determination for variable radius and time lag between flash count and precipitation timeframe for Chania precipitation station for event 1 (Table 1).

number of flashes and the precipitation was estimated using the squared Pearson coefficient of determination $r^{2}$. The case of rain without any lightening, or vice versa, was included in the analysis. The methodology does not use threshold values to exclude the possibility of both zero rainfall and zero flash count within the total period of a storm event. This constrain could lead to enhanced determination of coefficients and is a subject of future work. Figure 3 presents an example of the results obtained for Chania station for event 1 (Table 1). Correlation results were tested for its statistical significance at a $95 \%$ confidence level.

\section{Results and discussion}

For each station, the average coefficient of determination $\left(r^{2}\right)$ between the 16 events was estimated for the same variable radius $R$ and variable time-lag (TL). The optimum radius $R$ and time-lag (TL) for each station obtained (in terms of correlation) is presented in Table 2. Among all stations, the average $r^{2}$ ranged between 0.19 and 0.48 with a mean value of 0.31 , for an optimum $R$ ranging from $5 \mathrm{~km}$ to $45 \mathrm{~km}$ with a mean of $15 \mathrm{~km}$, and TL of flash count prior precipitation accumulation from 0 to $40 \mathrm{~min}$ with an average of $15 \mathrm{~min}$ (Table 2). Results of upper and lower bounds of coefficients of determination were attained at $95 \%$ significance level (s.l.) and percentage of the statistically significant events for each station among the 16 analysed events. The average upper bound of $r^{2}$ at $95 \%$ s.l. estimated at 0.39 , ranging from 0.23 to 0.57 , while the average lower bound of $r^{2}$ ranged between 0.07 and 0.38 with a mean of 0.20 . Correlations are statistical significant for $90 \%$ of the events, at the selected significance level. Some stations exhibit a more significant correlation than others but the overall correlation performance in terms of statistical significance is high. Figure 1 illustrates spatially the attained $r^{2}$ (Fig. 1d), corresponding to the optimum $R$ (Fig. 1b) and the optimum TL (Fig. 1c) for each station over the study area of Crete.

The linear correlation between the flash count and the precipitation for all the events and meteorological stations was found to vary between almost 0 and 0.97 with a mean value of 0.33 . Among the sixteen analysed storm events, four of them triggered medium to severe floods in several areas of Crete (Table 1). Linear regression for all events over each station was considered for the optimum R and TL values. Figure 4 presents the regression lines of maximum attained coefficient of determination at specific radius and time lag per station for the sixteen events. It was found that for 9 out of 12 stations, the regression line with the higher slope corresponds to a flood event occurring in Crete, denoting a general regime of high lightning activity associated with a flood occurrence. For seven events the second steeper regression line, also corresponded to a flood event. Moreover, for 11 stations, either the first or the second steeper regression line corresponds to a flood event. There is a clear indication that the number of flashes that occur during a precipitation event is related to precipitation depth when the latter is adequate to produce a flood event. Further analysis shows that there is no significant trend between coefficient of determination and station location or elevation of each meteorological station.

Figure 5 presents the maximum attained coefficient of determination at specific radius and time lag per station for the sixteen events. There is no clear difference of the value of coefficient of determination among flood and non-flood events. Some stations exhibit clearly higher correlation (Chania, Vrisses, Rethinmo) than others (Fragma, Spili), possibly due to the local nature of the phenomenon. The maximum correlation between the lightning and rainfall data is obtained for shorter time lags for the flood events $(15 \mathrm{~min})$ than the non-flood events $(25 \mathrm{~min})$. This result could reflect the faster propagation speed (movement) of violent flood triggering thunderstorms due to high convective activity and related to the shorter lifetime of the storm cells. Furthermore, there is a clear difference of the effective radius among flood and nonflood events. The average radius of the corresponding maximum attained correlation for flood events is shorter when compared with non-flood events. These results are in agreement with those of Michaelides et al. (2010), who found that the majority of frontal events show high values of the coefficient of determination for the $15 \mathrm{~km}$ radius and could be connected to the size (horizontal dimensions) of the cumulonimbus cloud under different conditions.

Focusing on the flood triggering storms, Fig. 6 presents the spatial distribution of the maximum attained coefficient of determination at specific radius and time lag for the four flood events. The average of the maximum coefficient of determination from all the stations and for the four flood events is 0.41 ranging from 0 to 0.90 . Table 3 includes the average of the coefficients of linear regression (slope a and 
Table 2. Average coefficient of determination for the optimum combination of time lag and radius, average upper and lower bounds of coefficients of determination attained at $95 \%$ significance level (s.1.), number of gauged and number of the statistically significant events among the 16 analysed events, the average $P$-value of statistically significant events, and average number of samples $(N)$ used to derive correlations per gauging station per event. The location of the stations is presented in Fig. 1a., the optimum radius in Fig. 1b., the optimum time-lag in Fig. 1c. and the attained $r^{2}$ in Fig. 1d.

\begin{tabular}{|c|c|c|c|c|c|c|c|c|c|c|}
\hline Station & $\begin{array}{l}\text { Elevation } \\
\quad(\mathrm{m})\end{array}$ & $\begin{array}{l}\text { Time lag } \\
\text { [min] }\end{array}$ & $\begin{array}{c}\text { Radius } \\
{[\mathrm{km}]}\end{array}$ & $r^{2}$ & $\begin{array}{c}r^{2} \text { Lower bound } \\
\text { at } 95 \% \text { s.1. }\end{array}$ & $\begin{array}{c}r^{2} \text { Lower bound } \\
\text { at } 95 \% \text { s.1. }\end{array}$ & $\begin{array}{c}\text { Number of } \\
\text { gauged } \\
\text { events }\end{array}$ & $\begin{array}{c}\text { Number of } \\
\text { significant } \\
\text { event }\end{array}$ & $\begin{array}{c}\text { Average } P \\
\text { value of significant } \\
\text { events }\end{array}$ & $\begin{array}{c}\text { Average } N \text { per } \\
\text { gauging Station } \\
\text { per event }\end{array}$ \\
\hline Anogia & 801 & 10 & 20 & 0.24 & 0.19 & 0.31 & 14 & 13 & $2.85 \mathrm{E}-04$ & 101 \\
\hline Chania & 137 & 30 & 10 & 0.34 & 0.25 & 0.43 & 16 & 15 & $1.35 \mathrm{E}-03$ & 116 \\
\hline Fragma & 240 & 0 & 5 & 0.35 & 0.24 & 0.46 & 11 & 11 & $1.65 \mathrm{E}-07$ & 84 \\
\hline Heraclio Port & 10 & 10 & 5 & 0.48 & 0.38 & 0.57 & 12 & 11 & $2.68 \mathrm{E}-03$ & 81 \\
\hline Heraclio & 115 & 0 & 15 & 0.30 & 0.22 & 0.39 & 16 & 15 & $3.98 \mathrm{E}-03$ & 116 \\
\hline Ierapetra & 5 & 20 & 10 & 0.28 & 0.27 & 0.34 & 8 & 6 & $6.06 \mathrm{E}-05$ & 49 \\
\hline Paleochora & 3 & 30 & 45 & 0.22 & 0.16 & 0.32 & 15 & 14 & $3.00 \mathrm{E}-03$ & 112 \\
\hline Rethimno & 39 & 20 & 15 & 0.31 & 0.13 & 0.40 & 16 & 14 & $6.06 \mathrm{E}-08$ & 108 \\
\hline Samaria & 1250 & 0 & 15 & 0.32 & 0.15 & 0.38 & 14 & 14 & $6.42 \mathrm{E}-04$ & 107 \\
\hline Spili & 405 & 40 & 10 & 0.19 & 0.07 & 0.23 & 15 & 11 & $1.37 \mathrm{E}-03$ & 94 \\
\hline Tzermiado & 820 & 10 & 15 & 0.30 & 0.10 & 0.38 & 13 & 10 & $1.44 \mathrm{E}-03$ & 83 \\
\hline Vrisses & 58 & 10 & 20 & 0.41 & 0.18 & 0.47 & 16 & 16 & $4.06 \mathrm{E}-03$ & 122 \\
\hline Average & 323 & 15 & 15 & 0.31 & 0.20 & 0.39 & 13.8 & 12.5 & $1.57 \mathrm{E}-03$ & 98 \\
\hline
\end{tabular}

Table 3. Average coefficients, slope (a) and intercept (b) of linear regression $(y=a \cdot x+b)$ and average flash count rate for all flood and non-flood events for each station.

\begin{tabular}{|c|c|c|c|c|c|c|}
\hline & \multicolumn{4}{|c|}{ Average regression coefficients } & \multirow{3}{*}{$\begin{array}{r}\text { Average flash } \\
\text { count rate } \\
\text { for all } \\
\text { flood } \\
\text { events }\end{array}$} & \multirow{3}{*}{$\begin{array}{r}\text { Average flash } \\
\text { count rate } \\
\text { for all } \\
\text { non-flood } \\
\text { events }\end{array}$} \\
\hline & \multicolumn{2}{|c|}{ a (slope) [flash count $\mathrm{mm}^{-1}$ ] } & \multicolumn{2}{|c|}{$\mathrm{b}$ (intercept) [flash count $\mathrm{h}^{-1}$ ] } & & \\
\hline & for all flood events & for all non-flood events & for all flood events & for all non-flood events & & \\
\hline Anogia & 1.36 & 0.10 & 0.00 & 0.00 & 68 & 5 \\
\hline Chania & 0.47 & 0.12 & 0.00 & 0.00 & 23 & 7 \\
\hline Fragma & 0.43 & 0.04 & 0.16 & 0.00 & 22 & 2 \\
\hline Heraclio Port & 0.02 & 0.01 & 0.00 & 0.00 & 1 & 1 \\
\hline Heraclio & 1.24 & 0.11 & 0.93 & 0.02 & 63 & 6 \\
\hline Ierapetra & -0.01 & 0.07 & 0.00 & 0.00 & 0 & 4 \\
\hline Paleochora & 5.51 & 2.39 & 0.00 & 0.00 & 275 & 129 \\
\hline Rethimno & 2.07 & 0.28 & 0.00 & 0.00 & 103 & 14 \\
\hline Samaria & 0.84 & 0.16 & -0.39 & -0.04 & 42 & 8 \\
\hline Spili & 0.38 & 0.07 & 0.00 & 0.00 & 19 & 3 \\
\hline Tzermiado & 0.97 & 0.08 & 0.00 & 0.00 & 49 & 4 \\
\hline Vrisses & 1.46 & 0.51 & 0.00 & 0.00 & 73 & 25 \\
\hline Average for all stations & 1.23 & 0.33 & 0.06 & 0.00 & 62 & 17 \\
\hline
\end{tabular}

intercept b) for all flood and non-flood events for each station. There is a clear difference between the coefficients and especially for slope (a) of flood and non-flood events. The higher values of slope $a$ and intercept $b$ coefficients correspond to flood events as a result of increased lightning activity during their occurrence. A robust signal of higher flash count during flood events compared with non-flood events is apparent for all raingauges. During flood events an average lightning rate of 62 flashes per hour (Table 3) are recorded within the optimum radius of influence, corresponding to the maximum attained correlation while for the non-flood events flash rate is limited to an average of 17 per hour. Some stations exhibit an increased lightning activity even for nonflood events (Fig. 4), for example Paleochora station at the southwest part of the island, possibly attributed to local geographical effects. More specifically the results at event scale for the flood events are presented as follows:

a. The late autumn event of 22/11/2008 (Table 1: event \#5) with an overall duration of 17 hours affected mainly the eastern and central part of the island of Crete, causing extensive damages to properties and infrastructure. The maximum attained coefficient of 

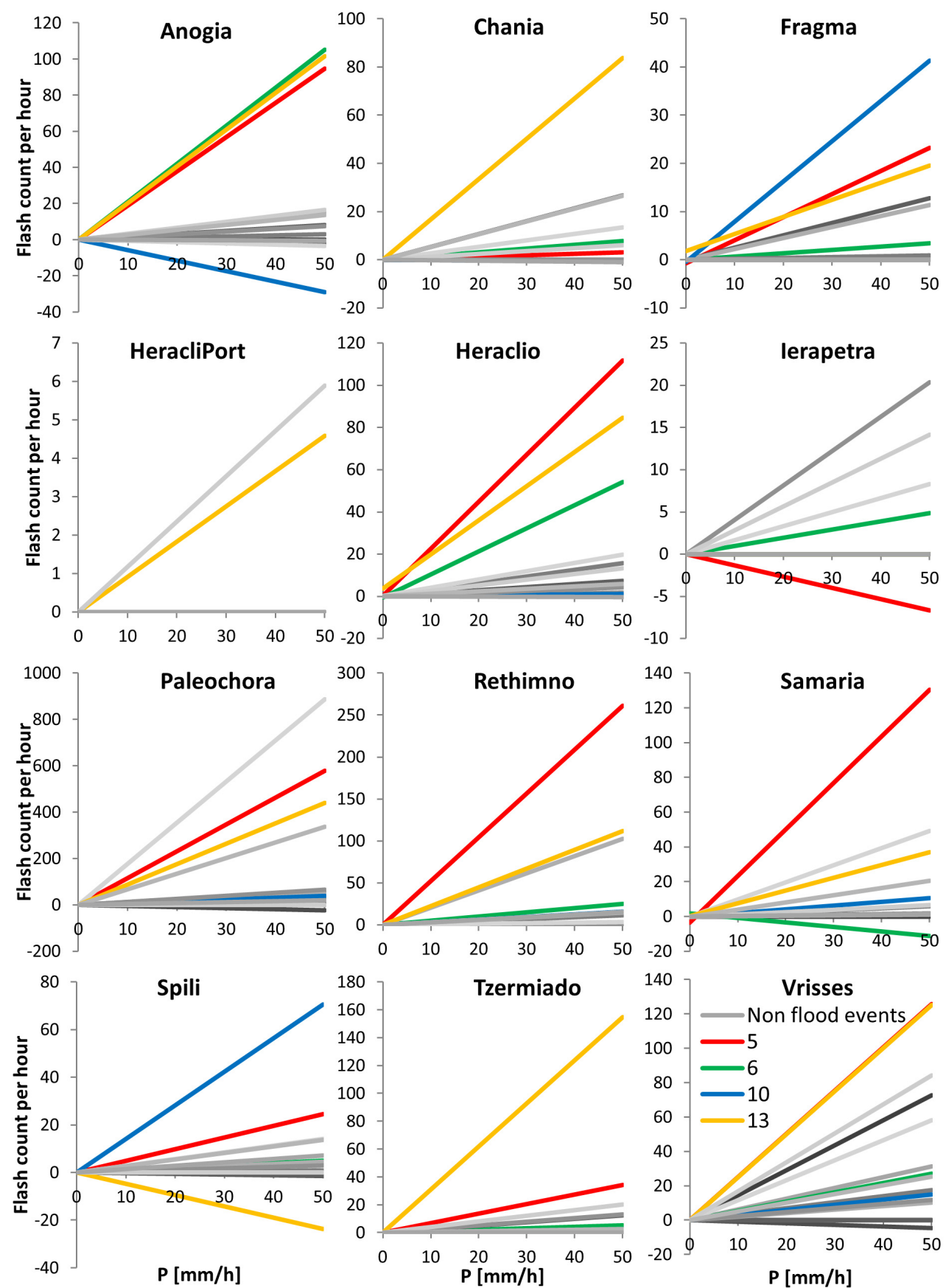

Fig. 4. Regression lines of maximum attained coefficient of determination at specific radius and time lag per station for the sixteen events. Non flood events marked in grey and flood events are marked in colour.

determination (Fig. 6) for the specific event ranges from station to station with a mean of $0.61 \pm 0.27$ for an optimum radius of $28 \pm 15 \mathrm{~km}$ and an optimum time lag of $12 \pm 10 \mathrm{~min}$.

b. The early winter event of 21-23/12/2008 (Table 1: event \#6), with an overall duration of $40 \mathrm{~h}$, produced high precipitation accumulations all-over the island of Crete. The maximum attained coefficient of determination (Fig. 6) from all stations, for this event, has a lower mean of $0.32 \pm 0.18$ for larger optimum radius of $35 \pm 15 \mathrm{~km}$ and a shorter optimum time lag of $5 \pm 5 \mathrm{~min}$, when compared with event 5 . 

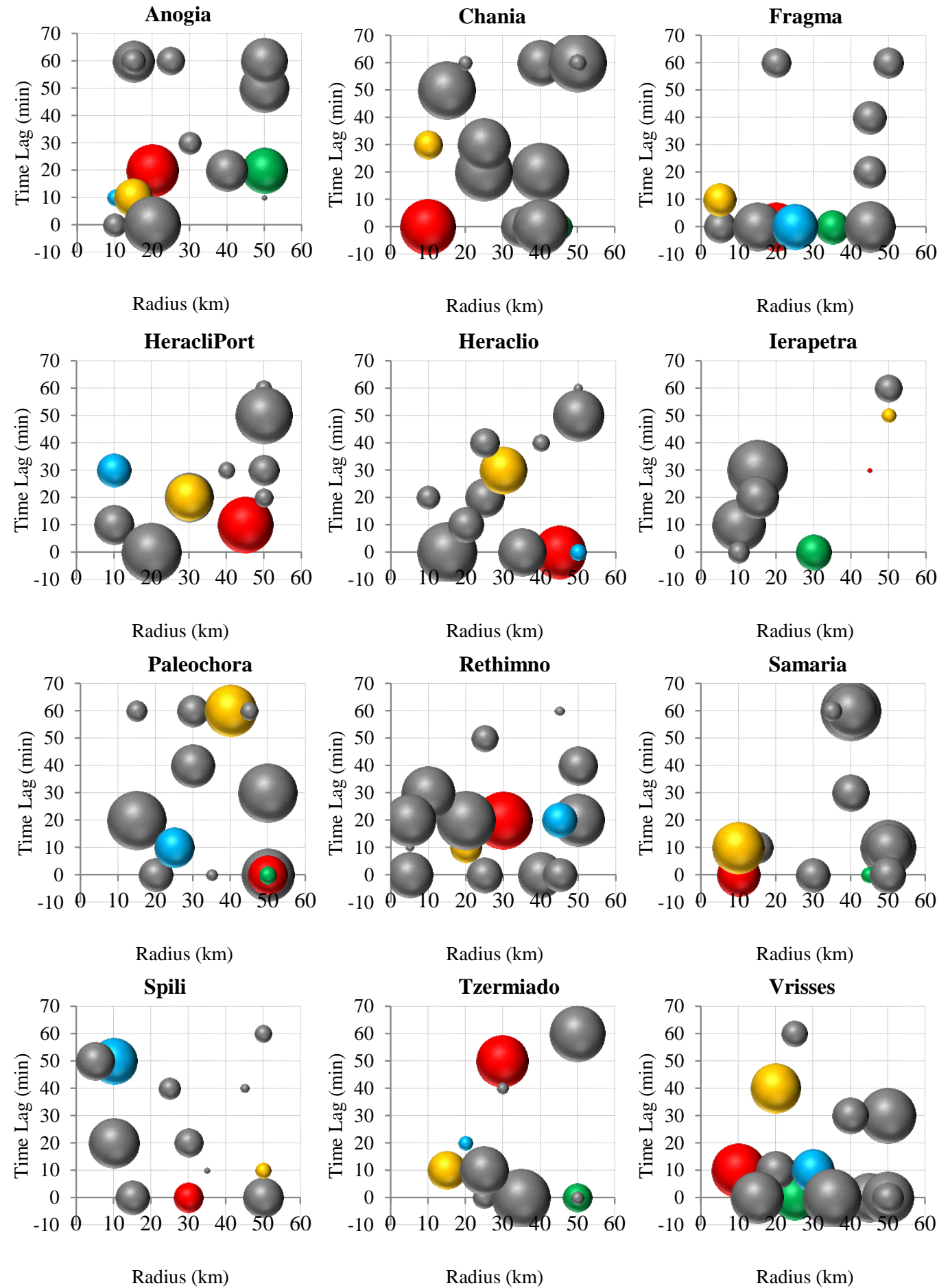

\begin{tabular}{|l|l|}
\hline $\begin{array}{l}\text { Legend } \\
\text { Coefficient of Determination } \\
0,20,4 \\
0,6\end{array}$ \\
\hline
\end{tabular}

Fig. 5. Maximum attained coefficient of determination at specific radius and time lag per station for the sixteen events. The size of the bubble represents the correlation coefficient. Non flood events marked in grey and flood events are marked in colour (red $=$ event 5 , green $=$ event 6 , blue $=$ event 10 , orange $=$ event 13 ). 


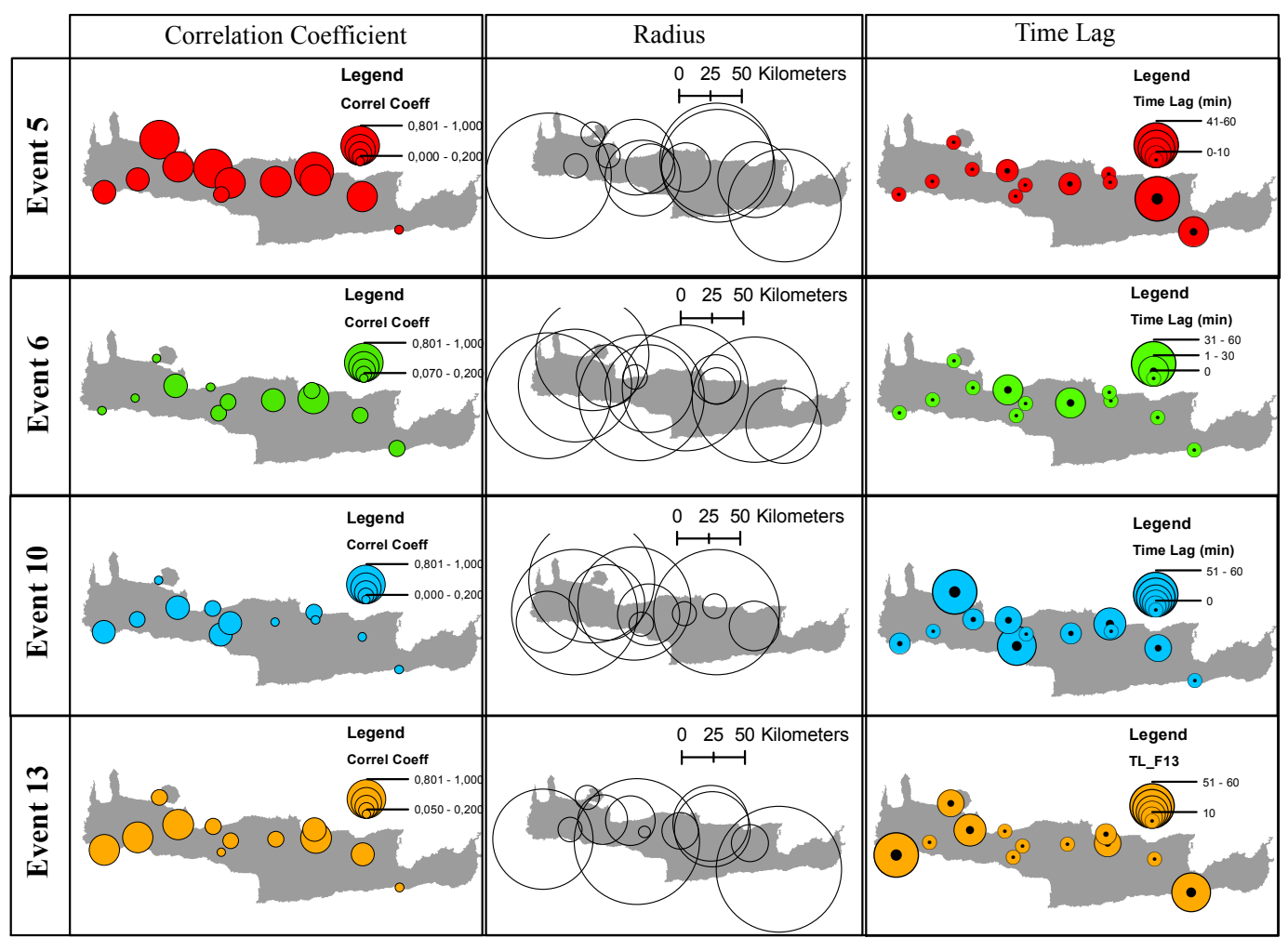

Fig. 6. Maximum attained coefficient of determination (1st column) at specific radius (2nd column) and time lag (3rd column) per station for the four flood events.

c. The spring event of 4-5/4/2009 (Table 1: event \#10), had an overall duration of $24 \mathrm{~h}$, impacted mainly the western and southern part of Crete. The maximum attained coefficient of determination (Fig. 6) from all stations, for this event, has a mean of $0.30 \pm 0.20$ for an optimum radius of $30 \pm 15 \mathrm{~km}$ and an optimum time lag of $20 \pm 20 \mathrm{~min}$.

d. The mid-autumn event of 25-26/10/2009 (Table 1: event \#13) lasted about $22 \mathrm{~h}$, affecting the eastern and central part of the island. The maximum attained coefficient of determination (Fig. 6) has a mean of $0.41 \pm 0.24$ for an optimum radius of $25 \pm 15 \mathrm{~km}$ and an optimum time lag of $25 \pm 18 \mathrm{~min}$.

\section{Conclusions}

The present study explores possible relationships between lightning activity, intense precipitation and flash flooding on the island of Crete. A preliminary attempt is made to investigate differences of these relationships between flood and non-flood producing storms. Study results were based on rainfall and lightning data provided from the National $\mathrm{Ob}$ servatory of Athens for sixteen intense rainfall events of the period 2008-2009. Four of these events were reported as flood events affecting several locations of the study area.

The conclusions of this study are subject to limitations regarding the used datasets and the methodology: (a) the detection efficiency of the lightning detection system used in this study, like all long-range networks, is far from being $100 \%$; (b) the density of the raingauges is rather low and therefore the data may not represent the area integrated rainfall; (c) a calculation constraint for the curve fitting and the determination coefficient is presented in the case of a time period of low or zero values for the rainfall and lightning flashes. This could lead to slightly enhanced correlation that could be avoided with the use of threshold values, and will be subject of future work. Thus, the results summarised in the following are considered as indicative. Moreover, the classification of four out of sixteen events as floods is based on flood reports, as the local measurement of a gauging station could miss the large values of rainfall rate associated with a flood event which could be very local. However, this definition of the flood events does not take into account the storm characteristics necessary to produce a flood, i.e. when large amounts of rainfall occur over areas unfavourable to a flood. We can reasonably suppose the lightning activity is better related to the rainfall than to the local conditions favourable or not to a flood. So, the relationship between flash count and rainfall (Table 3 and Fig. 4) depends a lot on the storm 
location from the rainfall station. For example a storm that crosses the gauge sites could be in its mature or dissipating stage and precipitation could practically cease. This particular storm could have produced high amount of rainfall triggering a flood in a distant location from the gauge sites, leading to underestimation of lightning-rainfall correlation estimates. Furthermore, one of the points that need further investigation is if the value of the slope (a) of the relationship is more representative of the spatial correspondence between the rainfall and the station, or if it is really indicative of a different behaviour in terms of lightning activity for a storm producing a flood.

The analysis of the correlation between precipitation and flash count was based on a multi-spatiotemporal approach of variable effective radius and time lag. The methodology consists in associating cumulative rainfall from a raingauge with the lightning flash count, calculated in various circular areas around it and during time intervals variously lagged before the rain measurement. The linear correlation between the flash count and the precipitation for all the events and meteorological stations was found to vary between 0 and 0.97 with a mean value of 0.33 . Correlations were statistical significant for the $90 \%$ of the events, at the $95 \%$ significance level. The increased value of the regression coefficients corresponding to flood events is a result of increased lightning activity during these events by an average factor of four times more flashes. This higher lightning activity could be associated with intense thunderstorms at its maximum vertical development stage. Milder lightning activity could be linked to less intense storms or storms after the dissipating stage, dominated by light to moderate stratiform rainfall and little lightning. The maximum correlation between the lightning and rainfall data is obtained for shorter time lags for the flood events $(15 \mathrm{~min})$ than the non-flood events $(25 \mathrm{~min})$, which could reflect the higher convective activity and the faster propagation speed of more intense thunderstorms. Some stations exhibit an increased lightning activity even for nonflood events, which is possibly attributed to local geographical effects, that deserves a further detailed study of local thunder cell activity. The high variability of the results (optimum correlated radius and time-lag) could be an indication that the analysed cases should be further classified on more specific criteria such as convection type. After further investigation of relationships between lightning and rainfall, site specific thresholds could be determined that could contribute to flood nowcasting. Increased lightning activity observed during studied flood events and associated with high rainfall rates (Fig. 4 and Table 3 ) is characterized by a higher slope (a) compared to non-flood event and that information could be used as a warning threshold.

Flood occurrence, in addition to the meteorological conditions that contribute to the activation of the phenomenon, depends on many other factors such as, topography and soil, hydrological and soil moisture regimes, and human interventions on floodways and natural channels. Consequently, a flood event may occur in a flood prone area under the influence of milder weather conditions than in less flood "sensitive" area. For the present study the discrimination among flood and non-flood events was based on flood facts and reports in cooperation with local authorities. To differentiate between flood and non-flood producing storms, one needs to analyze more parameters including synoptic conditions, thermodynamic criteria like instability and moisture supply, local climatic characteristics and dominant flash flood hydrological generating processes. The uncertainty will be reduced and quantificative results can be provided on short term alarm warnings. The events analyzed in this study with additional events for the period 2010-2011 will be the subject of future research in light of a more holistic approach focusing on flood triggering mechanisms.

Acknowledgements. The authors gratefully acknowledge the two anonymous reviewers for their comments and suggestions that helped to improve the manuscript.

Edited by: A. Mugnai

Reviewed by: two anonymous referees

\section{References}

Barnolas, M., Atencia, A., Llasat, M. C., and Rigo, T.: Characterization of a Mediterranean flash flood event using raingauges, radar, GIS and lightning data, Adv. Geosci., 17, 35-41, doi:10.5194/adgeo-17-35-2008, 2008.

Gaume, E., Bain, V., Bernardara, P., Newinger, O., Barbuc, M., Bateman, A., Blaškovièová, L., Blöschl, G., Borga, M., Dumitrescu, A., Garcia, J., Irimescu, A., Kohnova, S., Koutroulis, A., Marchi, L., Matreata, S., Medina, V., Preciso, E., SempereTorres, D., Stancalie, G., Szolgay, J., Tsanis, I., Velasco, D., and Viglione, A.: A collation of data on European flash floods, J. Hydrol., 367, 70-78, 2009.

Grillakis, M. G., Tsanis, I. K., and Koutroulis, A. G.: Application of the HBV hydrological model in a flash flood case in Slovenia, Nat. Hazards Earth Syst. Sci., 10, 2713-2725, doi:10.5194/nhess-10-2713-2010, 2010.

Harats, N., Ziv, B., Yair, Y., Kotroni, V., and Dayan, U.: Lightning and rain dynamic indices as predictors for flash floods events in the Mediterranean, Adv. Geosci., 23, 57-64, doi:10.5194/adgeo23-57-2010, 2010.

Katsanos, D., Lagouvardos, K., Kotroni, V., and Argiriou, A.: Combined analysis of rainfall and lightning data produced by mesoscale systems in the Central and Eastern Mediterranean, Atmos. Res., 83, 55-63, 2007.

Kempf, N. M. and Krider, E. P.: Cloud to ground lightning and surface rain fall during the Great Flood of 1993, Mon. Weather. Rev., 131, 1140-1149, 2003.

Kotroni, V. and Lagouvardos, K.: Lightning occurrence in relation with elevation, terrain slope and vegetation cover over the Mediterranean, J. Geophys. Res. Atmos., 113, D21118, doi:10.1029/2008JD010605, 2008.

Koutroulis, A. G. and Tsanis, I. K.: A method for estimating flash flood peak discharge in a poorly gauged basin: Case study for 
the 13-14 January 1994 flood, Giofyros basin, Crete, J. Hydrol., 385, 1-4, 150-164, 2010.

Koutroulis, A. G., Tsanis, I. K., and Daliakopoulos, I. N.: Seasonality of floods and their hydrometeorologic characteristics in the island of Crete, J. Hydrol., 394, 1-2, 90-100, 2010.

Lagouvardos, K., Kotroni, V., Betz, H.-D., and Schmidt, K.: A comparison of lightning data provided by ZEUS and LINET networks over Western Europe, Nat. Hazards Earth Syst. Sci., 9, 1713-1717, doi:10.5194/nhess-9-1713-2009, 2009.

Llasat, M. C., Llasat-Botija, M., Prat, M. A., Porcú, F., Price, C., Mugnai, A., Lagouvardos, K., Kotroni, V., Katsanos, D., Michaelides, S., Yair, Y., Savvidou, K., and Nicolaides, K.: High-impact floods and flash floods in Mediterranean countries: the FLASH preliminary database, Adv. Geosci., 23, 47-55, doi:10.5194/adgeo-23-47-2010, 2010.

Michaelides, S. C., Savvidou, K., Nicolaides, K. A., and Charalambous, M.: In search for relationships between lightning and rainfall with a rectangular grid-box methodology, Adv. Geosci., 20, 51-56, doi:10.5194/adgeo-20-51-2009, 2009.

Michaelides, S., Savvidou, K., and Nicolaides, K.: Relationships between lightning and rainfall intensities during rainy events in Cyprus, Adv. Geosci., 23, 87-92, doi:10.5194/adgeo-23-872010, 2010.

Naoum, S. and Tsanis, I. K.: Orographic precipitation modeling with multiple linear regression, J. Hydrol. Eng., 9, 79-102, 2004.
Pineda, N., Bech, J., Rigo, T., and Montanyà, J.: A mediterranean nocturnal heavy rainfall and tornadic event. Part II: Total lightning analysis, Atmos. Res., 100, 4, 305-782, doi:10.1016/j.atmosres.2010.10.027, 2010.

Price, C. and Federmesser, B.: Lightning-rainfall relationships in Mediterranean winter thunderstorms, Geophys. Res. Lett., L07813, doi:10.1029/2005GL024794, 2006.

Soula, S., Sauvageot, H., Molinie, G., Mesnard, F., and Chauzy, S.: The CG lightning activity of storm causing a flashflood, Geophys. Res. Lett., 25, 1181-1184, 1998.

Soula, S. and Chauzy, S.: Some aspects of the correlation between lightning and rain activities in thunderstorms, Atmos. Res., 56, 355-373, 2001.

Tapia, A., Smith, J. A., and Dixon, M.,: Estimation of Convective Rainfall from Lightning Observations, J. Appl. Meteor., 37, 1497-1509, doi:10.1175/15200450(1998)037<1497:EOCRFL>2.0.CO;2, 1998,

Zhou, Y., Qie, X., and Soula, S.: A study of the relationship between cloud-to-ground lightning and precipitation in the convective weather system in China, Ann. Geophys., 20, 107-113, doi:10.5194/angeo-20-107-2002, 2002. 